
Not for reproduction, distribution or commercial use.

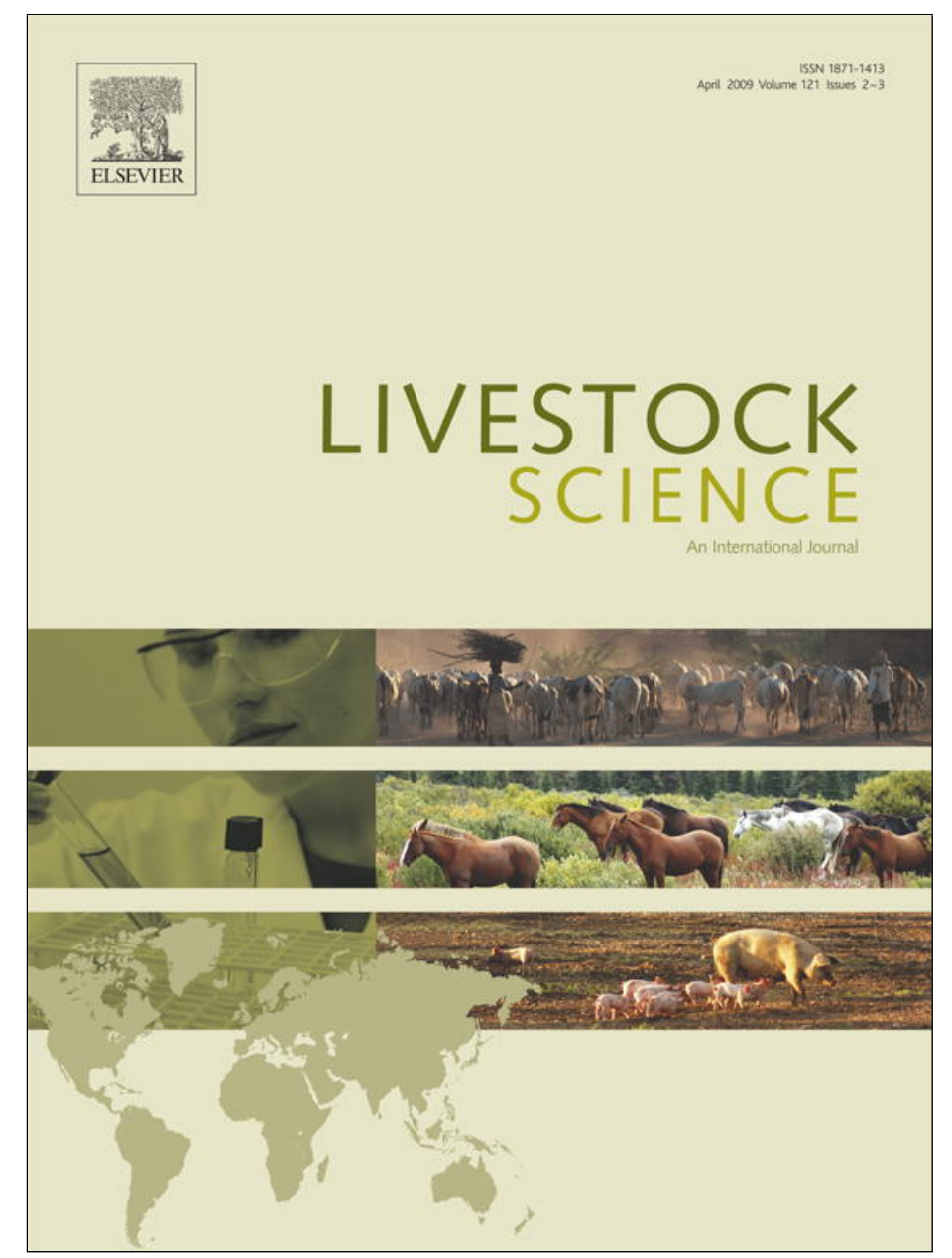

This article appeared in a journal published by Elsevier. The attached copy is furnished to the author for internal non-commercial research and education use, including for instruction at the authors institution and sharing with colleagues.

Other uses, including reproduction and distribution, or selling or licensing copies, or posting to personal, institutional or third party websites are prohibited.

In most cases authors are permitted to post their version of the article (e.g. in Word or Tex form) to their personal website or institutional repository. Authors requiring further information regarding Elsevier's archiving and manuscript policies are encouraged to visit:

http://www.elsevier.com/copyright 


\title{
Genetic and environmental impact on auction prices for Holstein cows
}

\author{
S. Schierenbeck, S. König *, H. Simianer \\ Institute of Animal Breeding and Genetics, University of Göttingen, 37075 Göttingen, Germany
}

\section{A R T I C L E I N F O}

\section{Article history:}

Received 4 July 2007

Received in revised form 30 June 2008

Accepted 2 July 2008

\section{Keywords:}

Dairy cattle

Auction price

Type traits

Genetic parameters

Economic weights

\begin{abstract}
A B S T R A C T
The aim of the present analysis was to determine the impact of a variety of traits and effects (i.e. production, type, health, management effects, pedigree information) on prices of Holstein cows sold at auction, and to estimate genetic (co)variance components between type traits and auction price. Results were used to derive economic weights for type traits. Data of 1565 cows in first parity were collected at six monthly auction sales from August 2005 through January 2006. Seventeen linear type traits and body condition (scale 1 to 9), and four type composites (dairy character, body, feet and legs, and udder; scale 65 to 88) were scored by two classifiers in the auction hall before cows were sold. Analysis of variance revealed a highly significant impact $(P<0.001)$ of auction date, test day milk yield, stage of lactation, origin of sire, and miscellaneous defects on auction price. The most expensive cows were sold in August, they were from foreign proven sires, they had a high level of test day milk yield, and they were free from defects related to udder, feet and legs, or milkability. The feet and leg, udder, and body composite also had a significant effect on the price $(P<0.001)$, with higher scores being associated with higher prices. The opposite association was found for dairy character $(P<0.01)$. Utilizing results from regression analysis, economic weights per genetic standard deviation were highest for linear scored rear udder height $(1.23 €)$, front teat placement $(0.97 €)$, and strength $(0.80 €)$, but were negative for dairy character $(-0.69 €)$. Genetic parameters for linear type traits scored at the auction date were consistent with literature reports. Heritability for auction price was 0.27 , and auction price was genetically positively related to the feet and leg (0.55), udder (0.55), and body composite ( 0.21$)$. A relative breeding value for auction price was estimated for 27 influential sires, and correlated with official indices for production, conformation, somatic cell count, functional herd life, fertility, and the total net merit index. Correlations were $0.15,0.21,0.11,0.03,0.05$, and 0.19 , respectively. Auction price in combination with type scores and information related to farm management provide valuable information for genetic analysis in dairy cattle, and results can be used to increase dairy cow profitability.
\end{abstract}

(c) 2008 Elsevier B.V. All rights reserved.

\section{Introduction}

Worldwide, conformation traits are included in most of the national selection indices for Holstein cattle (Miglior et al., 2005). They are generally used for the national genetic evaluation as indicator traits for udder health (Boettcher et al., 1998 ), or to predict the length of productive life (Bünger et al., 2001; Schneider et al., 2003; Sewalem et al., 2004). Type traits have a long tradition in German dairy cattle breeding programs

\footnotetext{
* Corresponding author. Tel.: +49 551 395670; fax: +49 551395587.

E-mail address: skoenig2@gwdg.de (S. König).
}

(Mügge et al., 1999), and a high emphasis on conformation traits in current breeding goals and selection decisions was reported by Swalve and Höver (2003) and König et al. (2007). However, the inclusion of conformation traits in an overall breeding goal through selection index theory can cause problems. Sophisticated methods for the derivation of economic weights (e.g. Amer et al., 1994) demand a direct impact of traits on costs and revenues, but some conformation traits describing the "beauty" of a cow have only a hypothetical weight (Sölkner et al., 1999).

A possible alternative to derive economic weights for type traits is described by Fürst-Waltl et al. (2004) and Krogmeier et al. (2006). These authors determined the impact of several 
type traits on auction prices of heifers and of cows, respectively. Both studies, recently conducted in the Simmental dual purpose breed and in Brown-Swiss dairy cattle, revealed a substantial impact of udder, conformation, frame, and rump structure on the market price. Regression analysis, i.e. the change in market price per one unit increase in the score (in genetic standard deviations) for the respective type trait, can be used to derive economic weights (Krogmeier et al., 2006).

The incorporation of type traits in complex breeding goals and the early prediction of longevity through type traits is associated with another problem. It is questionable whether subjectively scored type traits are a reliable database for complex statistical analyses. Beside the subjective classification for type traits, several studies (e.g. Weigel and Lawlor, 1994; Gengler et al., 2006) focused on the problem of heterogeneity in variance and covariance components. In the study by Gengler et al. (2006), heterogeneity of variances was found across different subsets stratified by the size of contemporary groups, the parity of cows, and the average classification for the respective type trait. A substantial heterogeneity of heritabilities for type traits within different regions in Germany was also found by Bethge et al. (2005), mainly for traits such as foot angle which are difficult to score in the field. A further problem is that classifiers varied in their score given for the same animal or in the range of the linear scale they used (Bowden, 1982; Swalve and Flöck, 1990; Veerkamp et al., 2002). Although these factors can often be adjusted before genetic evaluation (Brotherstone et al., 1990), a harmonisation of classification results would contribute to more authenticity. Hence, the advantages of a general classification of type traits at auction are as follows: 1.) Several classifiers can score the same animal and several hundred animals can be scored per day, 2.) cows for selling at auction are prepared and showcased similar to each other which could minimize bias in statistical analyses due to preferential treatment (Kuhn et al., 1994), and 3.) breeding organisations save expenses when data recording is more centralized (Swalve and König, 2007).

In the last decade, on average more than 26,000 auction sales per year of breeding stock were transacted in Germany for Holstein dairy cattle (ADR, 2005), and 75\% of all sales were from cows in first parity. Based on these impressive quantities, many breeders generate an additional income by selling surplus female cattle at auction. Knowledge about management related characteristics on auction prices, e.g. the optimal length of days in milk or age at first calving, is valuable information for a more economical sales strategy. So far, there were only a few studies addressing this topic in the Holstein breed, and most of them are somewhat out-dated (e.g. Placke, 1982; Ruff et al., 1983).

The objectives of this study were: 1.) to determine the most important management characteristics to achieve higher prices on sale, 2.) to determine the impact of type traits on auction prices for a further application in deriving economic weights, and 3.) to estimate genetic parameters for the trait 'auction price'.

\section{Materials and methods}

The dataset comprised auction prices, test day production records, and type scores of 1565 first-lactation Holstein cows marketed at six monthly auctions between August 2005 and
January 2006 at one auction place in North-West Germany. Seventeen linear type traits and body condition (scale 1 to 9 ), and five type composites (dairy character, body, feet and legs, udder, final score; scale 65 to 88 ) were scored by two classifiers in the auction hall before cows were sold. Both classifiers worked simultaneously on all auction dates and scored the animals alternating. The final score combines the composites for dairy character, body, feet and legs, and udder by weighting factors of $0.15,0.20,0.25$, and 0.40 , respectively. A more detailed description related to the recorded linear type traits and type composites for genetic evaluation in German Holstein dairy cattle is given by the VIT (2007). All cows were inspected by a veterinarian at the auction date and deficiencies like clinical mastitis, light quarters, udder warts, substantial feet and leg problems, and obvious reproductive failures were announced during the sale by the auctioneer. Official announcements also included the declaration of insufficient milkability below $1.8 \mathrm{~kg} / \mathrm{min}$. A second dataset consisted of 305-d lactation records and type scores of dams. Variables related to the sires, such as estimated breeding values (EBV) and origin (i.e. German young sire, German proven sire, foreign proven sire, or natural service) were used from the official database for international genetic evaluation from August 2005. Four different models were applied to investigate the impact of type composites and of linear type traits on auction price, and to estimate genetic parameters.

\subsection{Model 1 for type composites}

The impact of fixed effects as summarized in Table 1 with a main focus on fixed effects of the four type composites (dairy character, body, feet and legs, udder) on auction price was analysed using the GLM procedure (SAS, 1999). Model 1 was:

$y_{i}=\mu+F_{i}+e_{i}$

where

$y_{i j} \quad$ Auction price of the $i$-th animal

$\mu \quad$ Overall mean

$F_{i} \quad$ Representing all fixed effects for animal i (see explanations in Table 1 )

$e_{i} \quad$ Random residual effect

\subsection{Model 2 for linear scored type traits}

The linear type traits can be separated into four categories (dairy character, body, feet and legs and udder; Table 2). Model 2 was identical to model 1 apart the following changes: a) when analysing the regression of auction price on BCS and dairy character, the fixed effect of the dairy character composite was removed from the model, b) when analysing simultaneously the regression of auction price on stature, body depth, strength, rump angle, and rump width, the fixed effect of the body composite was removed from the model, c) when analysing simultaneously the regression of auction price on rear leg side view, foot angle, hocks, and rear leg set rear view, the fixed effect of the feet and leg composite was removed from the model, and d) when analysing simultaneously the regression of auction price on rear udder height, 
Table 1

Levels and $P$-values of fixed effects from model 1 ( $F$-test, sum of squares type III)

\begin{tabular}{|c|c|c|}
\hline Fixed effect & Levels of fixed effects & $P$-value \\
\hline Date of auction & August, September, October, November, December, January & $<0.001$ \\
\hline Stage of lactation & $\leq 14$ days in milk (dim), $15-28 \mathrm{dim}, 29-42 \mathrm{dim}, 43-56 \mathrm{dim}, 57-70 \mathrm{dim}, \geq 71 \mathrm{dim}$ & $<0.001$ \\
\hline Age at first calving & $<25$ months, $25-27,9$ months, $28-30,9$ months, $31-33,9$ months, $\geq 34$ months & 0.059 \\
\hline Test day milk yield & $<26 \mathrm{~kg}, 26-27,9 \mathrm{~kg}, 28-29,9 \mathrm{~kg}, 30-31,9 \mathrm{~kg}, 32-33,9 \mathrm{~kg}, 34-35,9 \mathrm{~kg}, \geq 36 \mathrm{~kg}$ & $<0.001$ \\
\hline Somatic cell count & $\leq 100,000 ; 101,000-400,000 ; \geq 400,000$ & 0.004 \\
\hline 305-d milk yield of dam & $<7000 \mathrm{~kg}, 7000-8499 \mathrm{~kg}, 8500-9999 \mathrm{~kg}, \geq 10,000 \mathrm{~kg}$ & 0.053 \\
\hline Final score of dam & Not scored or $\leq 79$ points, $80-82$ points, $83-84$ points, $\geq 85$ points & 0.003 \\
\hline Announcement of udder deficiencies ${ }^{a}$ & Present, absent & $<0.001$ \\
\hline Announcement of feet and leg deficiencies ${ }^{b}$ & Present, absent & $<0.001$ \\
\hline Announcement of reproductive failures ${ }^{c}$ & Present, absent & 0.069 \\
\hline Announcement of milkability deficiencies & Present, absent & $<0.001$ \\
\hline Dairy character composite & $\leq 76$ points, $77-78$ points, $79-80$ points, $81-82$ points, $83-84$ points, $\geq 85$ points & 0.006 \\
\hline Body composite & $\leq 76$ points, $77-78$ points, $79-80$ points, $81-82$ points, $83-84$ points, $\geq 85$ points & $<0.001$ \\
\hline Feet and leg composite & $\leq 76$ points, $77-78$ points, $79-80$ points, $81-82$ points, $83-84$ points, $\geq 85$ points & $<0.001$ \\
\hline Udder composite & $\leq 76$ points, $77-78$ points, $79-80$ points, $81-82$ points, $83-84$ points, $\geq 85$ points & $<0.001$ \\
\hline
\end{tabular}

a Announcements of udder deficiencies imply e.g. presence of mastitis or surplus teats.

b Announcements of feet and leg deficiencies imply e.g. hyperplasia interdigitalis or digital dermatitis.

c Announcements of reproductive failures imply e.g. retained afterbirth or cleaning still in progress.

suspensory ligament, front teat placement, rear teat placement, fore udder attachment, udder depth, and teat length, the fixed effect of the udder composite was removed from the model. This strategy avoids double-counting of traits. The impact of all linear type traits apart for the traits with an intermediate optimum (rump angle, rear leg side view, teat placement rear, and teat length) was modelled as a linear regression, because quadratic or cubic terms were not significant at all $(P>0.05)$. The quadratic coefficients were found to be statistically significant for the four linear traits rump angle, rear leg side view, teat placement rear, and teat length. Hence, these traits were taken into account with an intermediate optimum applying the following strategy: The highest value was given for the score of the intermediate optimum, and deviations from the optimum, regardless below or above, received the same score in the range from 1 to 5 .

2.3. Model 3 and 4 to estimate genetic parameters for auction price and type traits

Estimation of genetic parameters for the four type composites, the final score, and auction price was done using bivariate animal models for all combinations of type

Table 2

Regression coefficients on auction price (standard errors in brackets), variance components, heritabilities ${ }^{\mathrm{a}}$, and economic weights for body condition score and 17 linear type traits

\begin{tabular}{|c|c|c|c|c|c|}
\hline Linear type trait & Regression coefficient ( $€ /$ score point) & $\sigma_{\mathrm{a}}^{2}$ & $\sigma_{\mathrm{e}}^{2}$ & $h^{2}$ & Economic weight $\left(€ / \sigma_{a}\right)$ \\
\hline Body condition score & $5.10(2.40)$ & 0.32 & 1.24 & 0.20 & 0.29 \\
\hline \multicolumn{6}{|l|}{ Dairy character } \\
\hline Dairy character & $-9.49(2.39)$ & 0.54 & 1.30 & 0.29 & -0.69 \\
\hline \multicolumn{6}{|l|}{ Body } \\
\hline Stature (in cm) & $1.95(1.04)$ & 9.19 & 7.95 & 0.54 & 0.59 \\
\hline Strength & $14.64(3.95)$ & 0.30 & 0.90 & 0.25 & 0.80 \\
\hline Rump angle & $1.93(3.25)$ & 0.33 & 0.73 & 0.31 & 0.11 \\
\hline Rump width & $2.31(3.28)$ & 0.35 & 0.74 & 0.32 & 0.14 \\
\hline \multicolumn{6}{|l|}{ Feet and legs } \\
\hline Rear leg side view & $2.13(2.96)$ & 0.15 & 1.13 & 0.13 & 0.08 \\
\hline Foot angle & 3.09 (2.09) & 0.11 & 0.87 & 0.11 & 0.10 \\
\hline Hocks & $9.18(2.63)$ & 0.42 & 1.50 & 0.22 & 0.59 \\
\hline \multicolumn{6}{|l|}{ Udder } \\
\hline Rear udder height & $29.78(3.61)$ & 0.17 & 0.88 & 0.16 & 1.23 \\
\hline Suspensory ligament & $1.04(2.51)$ & 0.30 & 1.89 & 0.14 & 0.06 \\
\hline Front teat placement & $15.14(3.63)$ & 0.41 & 0.61 & 0.40 & 0.97 \\
\hline Rear teat placement & $8.39(4.01)$ & 0.32 & 0.64 & 0.33 & 0.47 \\
\hline Fore udder attachment & $5.81(3.28)$ & 0.45 & 1.35 & 0.25 & 0.39 \\
\hline Udder depth & $-3.76(2.97)$ & 0.49 & 0.60 & 0.45 & -0.26 \\
\hline Teat length & $14.14(3.69)$ & 0.23 & 0.84 & 0.22 & 0.67 \\
\hline
\end{tabular}

\footnotetext{
a Standard errors of heritabilities were in the range from 0.07 to 0.11 .
} 


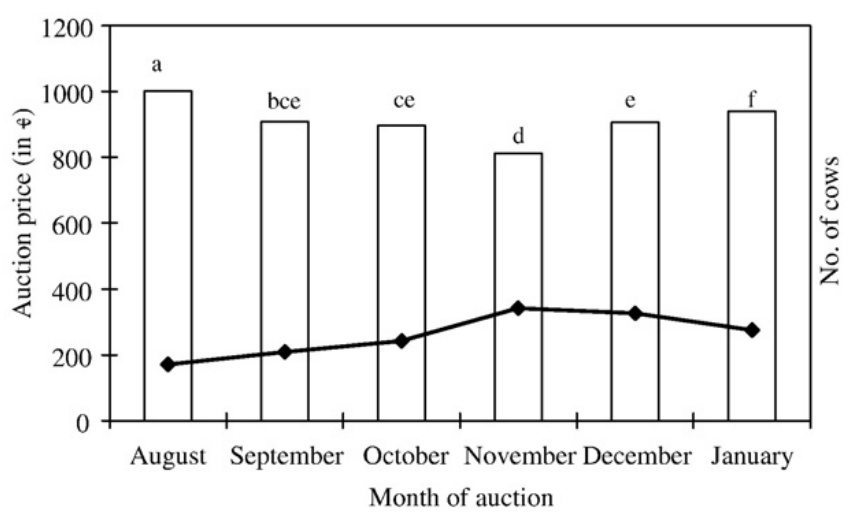

Fig. 1. No. of sold cows (black solid line) and LSMeans for the trait "auction price" (in $€$, white bars) by month of auction. Different superscripts indicate significant differences of LSMeans $(P<0.05)$.

traits and auction price and applying the package ASReml (Gilmour et al., 2000). The model 3 for auction price was:

$y_{i j k l m}=\mu+\mathrm{SL}_{i}+\mathrm{FC}_{j}+\mathrm{DA}_{k}+a_{1}+e_{i j k l m}$

and for all type composites and final score, the model 4 was:

$y_{i j k l m n}=\mu+\mathrm{SL}_{i}+\mathrm{FC}_{j}+\mathrm{DA}_{k}+\mathrm{CF}_{1}+a_{m}+e_{i j k l m n}$

where SL is the fixed effect of stage of lactation, FC is the fixed effect of age at first calving, DA is the fixed effect of date of auction, a refers to the random animal effect, and CF is the fixed effect of the classifier. All other effects were defined as in model 1 . Model 4 was also used for unviariate analyses to estimate variance components for the eighteen linear type traits scored at auction. For genetic analyses, relationships among animals were considered back to base animals born in 1940.

\section{Results and discussion}

3.1. Impact of production, health, management effects, and type composites (model 1)

Significance values from analysis of variance for all fixed effects (type III test of fixed effects) are shown in Table 1. Most of the effects were highly significant $(P<0.001)$, apart from the 305 - $d$ milk yield of the dam, announcement of reproductive failures, age at first calving, and the dairy character composite.

A general overview for the number of sold cows in combination with least square means for auction price by month of

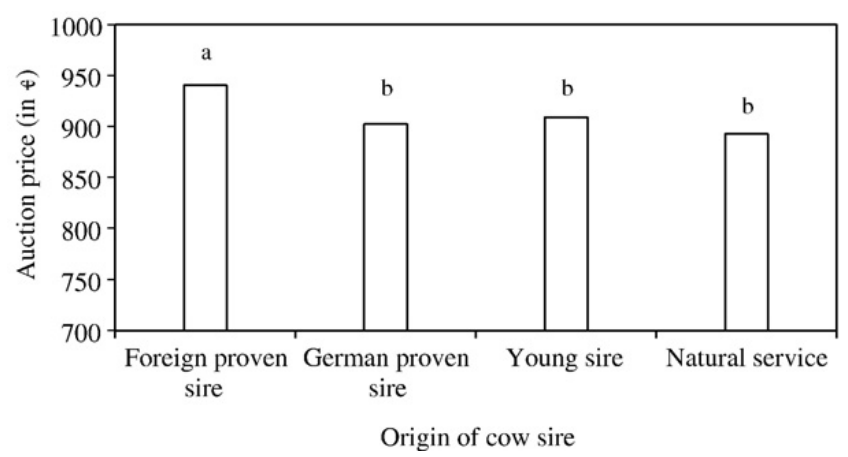

Fig. 2. LSMeans for the trait "auction price" (in $€$ ) by classes of origin of sire. Different superscripts indicate significant differences of LSMeans $(P<0.05)$.

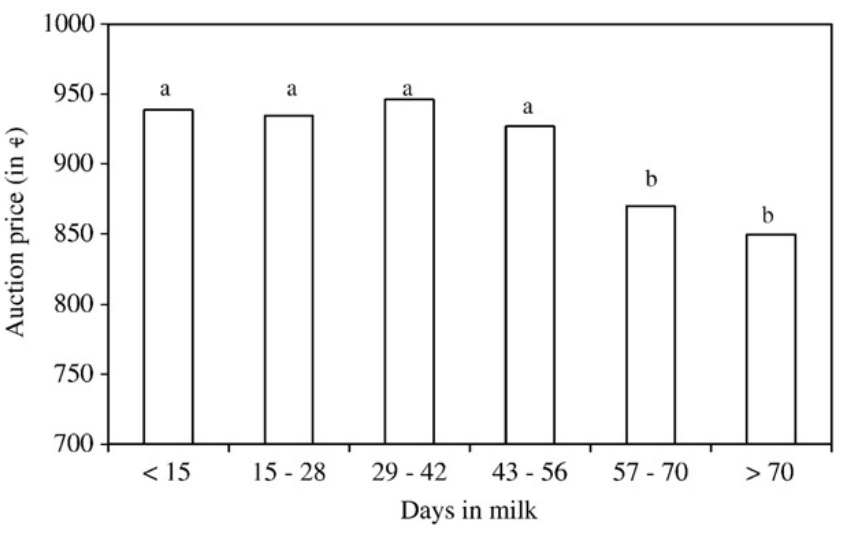

Fig. 3. LSMeans for the trait "auction price" (in $€$ ) by classes of days in milk Different superscripts indicate significant differences of LSMeans $(P<0.05)$.

auction is depicted in Fig. 1. According to the observed trend in previous years for different market places in Germany (ADR, 2005), the number of cows sold in November was twice as high compared to the number of cows sold in August, but auction prices were lower. Hence, the market price was mainly influenced by the ratio of supply and demand.

Age at first calving, another effect related to farm management, had no significant impact $(P>0.05)$ on auction price. Country of origin of the cows' sire (foreign proven, domestic proven, young bull without official EBV, or natural service) had a significant $(P<0.001)$ impact on auction price. Prices of daughters from foreign, proven sires were $29 €$ higher compared to the average market price (Fig. 2). As 50\% of all animals were bought by foreign customers, a reason for this fact might be that those customers favoured daughters from well-known international sires. Lowest prices were paid for daughters from natural service bulls.

As shown in Fig. 3, an increase of days in milk was associated with a decrease in price for more than 43 days in milk. The main intention of customers is to increase the total amount of milk production on their farms to fulfil the fixed fat quota. As a consequence, cows on sale having already exceeded their lactation peak achieved lower prices. Krogmeier et al. (2006) defined three classes for days in milk. In their study, prices for cows sold within the first 30 days after calving were about $30 €$ higher compared to cows being in a later stage of lactation.

The impact of test day milk yield on market prices is supported by results presented in Fig. 4. The difference in

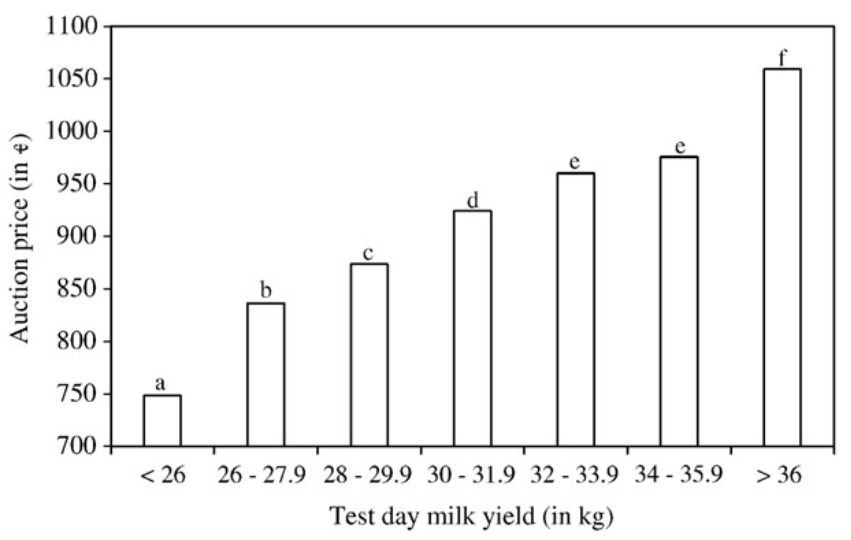

Fig. 4. LSMeans for the trait "auction price" (in $€$ ) by classes of test day milk yield. Different superscripts indicate significant differences of LSMeans $(P<0.05)$. 


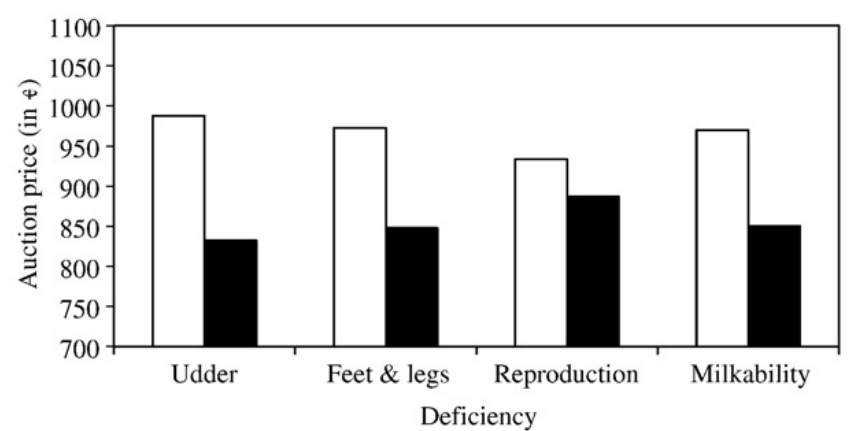

Fig. 5. LSMeans for the trait "auction price" (in €) for several kinds of deficiency announcements ( white bar= no announcement; black bar=announcement). All pair wise differences were significant apart from reproduction $(P<0.05)$.

market price for cows differing $10 \mathrm{~kg}$ in test day milk yield, e.g. when comparing prices in milk yield class $1(<26 \mathrm{~kg})$ and in milk yield class 7 ( $>36 \mathrm{~kg}$ ), was $311 €$. A similar result, i.e. an increase in auction price of $40.5 €$ per $1 \mathrm{~kg}$ of test day milk yield, was reported by Krogmeier et al. (2006). The impact of 305-d lactation milk yield of the dam on auction prices was of minor importance $(P>0.05)$, e.g. a difference of only $43 €$ was observed when comparing extreme classes above $10,000 \mathrm{~kg}$ and below $7000 \mathrm{~kg}$. This result corresponds to those from Krogmeier et al. (2006). Placke (1982) and Fürst-Waltl et al. (2004) found a substantial impact of dams' milk production on auction prices. However, heifers in their analyses did not have any production records. In such a case, customers put more emphasise on pedigree information.

The current status of a cow's health strongly determined purchase decisions. Announced deficiencies based on the veterinarians' inspections, i.e. mastitis, feet and leg problems, and reproductive failures, reduced the average market price by $151.40 €, 121.23 €$, and $50.96 €$, respectively (Fig. 5). An additional indicator for udder health is SCC (Philipsson et al., 1995). According to guidelines by Smith et al. (2001), SCC of cows in first parity should be below 100,000 , whereas the range from 100,000 to 200,000 indicates a possible infection, and 200,000 cells or more is a clear signal that an infection is occurring. In our study, test day SCC below 100,000 cells increased the average market price by $38.60 €$. The announcement for insufficient milkability below $1.8 \mathrm{~kg} / \mathrm{min}$ decreased the market price by $103.92 €$ (Fig. 5): a comprehensible decision, because milking speed of cows is strongly related to labour (Devir et al., 1993) and costs (Trilk et al., 2005) in dairy cattle farming.

The impact of type composites on auction price is shown in Fig. 6. As depicted, the score for the udder composite had a significant impact on auction price. Scores of 84 points or above resulted in $227 €$ higher prices compared to udder scores below 77 points. Krogmeier et al. (2006) found a similar price difference between the best and the worst udder class in Brown-Swiss and Simmental. Due to their desirable correlations to longevity (Bünger et al., 2001), and claw disorders (König et al., 2005), also higher scores for the feet and leg composite were associated with higher prices. The price difference between the two extreme classes was $126 €$. As shown by Fürst-Waltl et al. (2004), customers also paid significantly higher prices for cows having higher scores for the body composite. Somewhat surprising were higher prices for lower scores for the dairy character composite. Customers favoured well-conditioned cows, but sharpness at the withers (a main criterion for high scores for dairy character) is highly correlated with less strength and body weight (Dechow et al., 2003).

\subsection{Impact of linear type traits (model 2) and economic weights}

A main focus of this study was to determine the impact of linear type traits on auction price through the application of linear regression in model 2. Estimated regression coefficients for all linear scored type traits and BCS are provided in Tab. 2 . Among all type traits, the largest regression coefficient was estimated for rear udder height (29.78 €/point), followed by body depth (14.76 €/point), and strength (14.60 €/point). In addition to body depth, all other traits related to the body composite, i.e. stature, strength, rump angle, rump width, and BCS, had positive regression coefficients, indicating that customers favoured higher weights and more capacity of sold cows. As reported for the dairy character composite, also linear scored dairy character had a negative impact $(-9.49 € /$ point) on auction price. This poses the question whether scoring of dairy character should be continued. Dairy character is an indicator for milk production, but objectively measured test day milk yield is a much more accurate trait. The additional genetic gain in an overall breeding goal seems to be limited or even counterproductive when including the dairy character component as a predictor for milk yield.

Regression coefficients revealed a positive impact for all linear traits belonging to the feet and leg composite in the range from $2.13 € /$ point (rear leg side view) to $9.61 € /$ point (rear leg set rear view) on auction price. Heterogeneous results were found for linear traits of the udder complex, i.e. a pronounced positive impact of rear udder height on auction price ( $29.78 € /$ point), but neutral or slightly negative regression coefficients for suspensory ligament (1.04 €/point), and udder depth (-3.76 €/point), respectively. Harris et al. (1992) and Short and Lawlor (1992) reported moderately negative genetic correlations between fore udder attachment and udder depth with the three milk production traits. These results suggest that selection for improvement of milk production, which was the main criterion when making purchase decisions about cows at auction, will

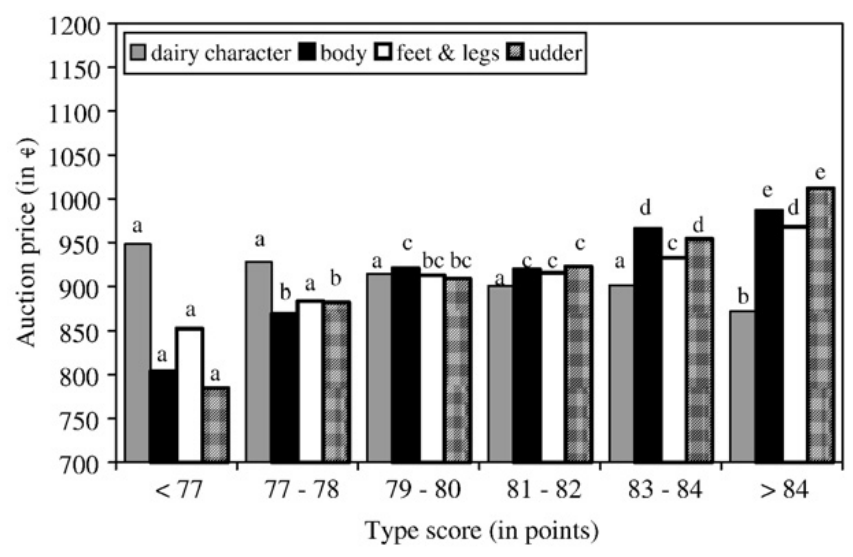

Fig. 6. LSMeans for the trait "auction price" (in $€$ ) by classes of scores for the type composites dairy character, body, feet \& legs, and udder. Different superscripts within type composites indicate significant differences of LSMeans $(P<0.05)$. 
Table 3

Variance components and heritabilities $\left(h^{2}\right)$ for auction price and type composites, and genetic correlations $\left(r_{\mathrm{g}}\right)$ between auction price and type composites

\begin{tabular}{lllll}
\hline Trait & $\sigma_{\mathrm{a}}^{2}$ & $\sigma_{\mathrm{e}}^{2}$ & $\sigma_{\mathrm{p}}^{2}$ & $h_{\mathrm{g}}^{2}$ \\
\hline Auction price & 7,375 & 19,991 & 27,366 & $0.27 \pm 0.06$ \\
Dairy character & 1.49 & 4.22 & 5.71 & $0.26 \pm 0.07$ \\
Body & 0.69 & 5.79 & 6.48 & $0.11 \pm 0.05$ \\
Feet and legs & 0.80 & 6.71 & 7.51 & $0.11 \pm 0.03$ \\
Udder & 0.70 & 6.22 & 6.92 & $0.10 \pm 0.16$ \\
Overall conformation & 0.35 & 2.89 & 3.24 & 0.04 \\
\hline
\end{tabular}

lead to unfavourable correlated response for udder depth. Hence, purchase decisions were not inevitably related to sustainable breeding strategies. The magnitude of front (14.14 €/point) and rear teat placement (8.39€/point), as well as teat length (14.89 $€ /$ point) could be expected, because these "workability" traits are important for the optimisation of the milking process (Rogers and Spencer, 1991), and they are positively correlated with udder health (Lund et al., 1994).

Regression coefficients from model 2 and additive genetic standard deviations $\left(\sigma_{\mathrm{a}}\right)$ from model 4 (Table 2 ) were used for an approximate calculation of economic weights for linear type traits. Economic weights expressed in $€ / \sigma_{\mathrm{a}}$ enable a neutral comparison of the importance of individual type traits rather than simple regression coefficients. Additionally, economic weights presented in Table 2 were accounted for the probability of an auction sale or of an exported heifer per average Holstein cow. According to FürstWaltl et al. (2004), economic values estimated from a selected pool of auction cows have to be transformed to values representing the whole population or an average cow in the herd. Hence, a realization factor of 0.1 was assumed, i.e. it was considered that on average $10 \%$ of the heifers in the population were sold. This means a multiplication of economic weights obtained from regression analyses by factor 0.1 .

The two most important traits were rear udder height (1.41 $\left.€ / \sigma_{\mathrm{a}}\right)$ and strength $\left(0.80 € / \sigma_{\mathrm{a}}\right)$. Fürst-Waltl et al. (2004) discussed the disadvantages of this approach, especially the differences in purchase decisions of cows sold in first parity at auction compared to pregnant heifers sold via "conventional" export. Further restrictions have to be applied if a sectoral model is used to derive economic weights. Within a sector, e.g. within the same country, higher prices for cows sold at auction (increased income for some milk producers), have to be compensated by higher costs for customers (increased costs for some other milk producers). An advantage of increased income (higher prices at auction) for some sellers implies the disadvantage of higher costs for buyers. Economic weights derived in this present study show the importance of individual type traits among each other, but additional and more sophisticated steps have to be applied to construct distinct sub-indices for conformation traits in an overall breeding goal. These steps, such as sensitivity analyses, are part of an ongoing research project (Lind et al., 2007).

A strict derivation of economic weights for conformation only based on the influence on auction prices will probably lead to an underestimation of conformation in a combined breeding goal. It should be considered that conformation has additional effects on dairy cow profitability. For example the improvement of the udder composite by one standard deviation was associated with labour time reduction by 54 min per cow and lactation (Blake and McDaniel, 1979).

\subsection{Genetic analyses (models 3 and 4)}

Heritabilities for 17 linear type traits and BCS as shown in Table 2 were in the wide range reported by Bethge et al. (2005) when analyzing type traits in 15 different regions within Germany. For example for foot angle, Bethge et al. (2005) estimated heritabilities in the range between 0.06 and 0.17 . The largest heritability among all linear type traits when using auction data was found for stature. Stature was the only objective measurement (in $\mathrm{cm}$ ), whereas the remaining traits were subjectively scored on the scale from 1 to 9 . Hence, accurate measurements can reduce the residual component and increase repeatabilities and reliabilities as well. Heritabilities for type composites scored on a 100 point scale were 0.26 for dairy character, 0.11 for body, 0.11 for feet and legs, 0.10 for udder, and 0.11 for the final score (Table 3 ). Heritabilities were relatively small, but, apart from the lower value for the body composite, similar to the results reported by Bethge et al. (2005).

As shown in the previous sections of the present study, auction price is determined by a multitude of traits, e.g. milk production, health, and type traits. From the genetic perspective, these results raised the idea to consider the trait "auction price" as an overall breeding goal, and to estimate genetic relationships between currently used national official indices and auction price. Heritability for auction price was 0.27 (Table 3 ) and therefore larger than all type composites. We found moderate to high genetic correlations between auction price and feet and legs (0.55), and auction price and the udder composite $(0.55)$. The genetic correlation between auction price and dairy character was close to zero. From the genetic point of view, there is no additional contribution of dairy character when defining the trait "auction price" as an ultimate breeding goal.

Estimated breeding values for auction price of all animals were standardised to a mean of 100 points and a standard deviation of 12 points. The newly constructed relative breeding value for auction (RZA) was correlated with all

Table 4

Correlations between the relative breeding value for auction price (RZA) and German national official relative breeding values for bulls and cows

\begin{tabular}{llc}
\hline Relative breeding value & $\begin{array}{l}\text { Bulls }(>10 \text { daughters sold } \\
\text { at auction) }\end{array}$ & $\begin{array}{c}\text { Cows sold } \\
\text { at auction }\end{array}$ \\
\hline Total merit index (RZG) & 0.19 & 0.29 \\
Production index (RZM) & 0.15 & 0.21 \\
Conformation index (RZE) & 0.21 & 0.33 \\
Somatic cell count index (RZS) & 0.11 & 0.10 \\
Functional herd life index (RZN) & 0.03 & 0.04 \\
Fertility index (RZZ) & 0.05 & -0.03 \\
\hline
\end{tabular}


official relative breeding values, i.e. the German total merit index (RZG), the production index (RZM), the conformation index (RZE), the somatic cell count index (RZS), the reproduction index (RZZ), and the functional herd life index (RZN). The relative weights of the sub-indices RZM, RZE, RZS, RZZ and RZN in the overall index RZG are 50\%, 15\%,5\%, 5\%, and $25 \%$, respectively. Details for the construction of all subindices are given by König et al. (2007). Table 4 shows the correlation coefficients between RZA and remaining relative breeding values for 27 bulls with at least 10 daughters sold at auction (reliability of RZA $>0.60$ ), and for the sold cows itself. The correlations were moderate for RZG, RZM, and RZE in the range between 0.15 (RZM of bulls) and 0.33 (RZE of cows), but close to zero for RZN and even negative $(-0.03)$ for RZZ of cows. However, when interpreting results, the limited sample size for bulls and the low reliabilities of EBVs for cows should be kept in mind. The low correlations between RZA and RZZ could be expected, because the customer has, apart from the announcement of reproduction deficiencies, no information available related to fertility of cows.

Based on the high number of more than 20,000 sold Holstein cows at auction per year, it seems to be a reasonable approach to store auction prices in a national electronic database, and to use this information as indicator traits for the improvement of accuracies of correlated national EBVs. For several dairy cattle breeders, auction sales substantially contribute to their monthly income. Profitability could be increased through the knowledge of RZA of individual sires.

\section{Conclusion}

As shown in this study, prices of cows sold at auction reveal several possibilities for analyses related to dairy cow profitability. First of all, the optimisation of management strategies for sales can contribute to additional income for dairy cattle farmers. The most important management effect to achieve higher prices was the choice of a market date early in lactation. A further opportunity, due to the reduced supply of cows on market during the summertime, could be to focus on auction sales in August or September. However, such a strategy implies inseminations in October or November, where heifers are usually kept outdoors. In addition to the identified management effects, there was a moderate genetic contribution to auction prices. Based on the moderate heritability of 0.27 for auction price, it is recommended to provide a relative breeding value for auction price (RZA), or to use auction price as an indicator trait for the improvement of the udder $\left(r_{\mathrm{g}}=0.55\right)$ and the feet and leg composite $\left(r_{\mathrm{g}}=0.55\right)$. The success in breeding programs in Nordic countries, e.g. reduced disease incidences and lower costs, was only possible due to the detailed and extended recording system (Heringstad et al, 2000). This implies the evaluation of all information sources, also including auction prices, for the general improvement in dairy cow profitability.

It is also possible to derive economic weights for type traits based on their impact on auction prices. However, important type traits identified in the present study through multiple regression analyses (e.g. body depth), are negatively related to functional herd life. Further concerns when deriving economic weights include eventual double-counting of type traits, or additional direct impact of type traits on dairy cow profitability such as reduced labour time.

\section{Acknowledgements}

We thank the breeding organisation "Masterrind", Verden for supplying auction prices and linear type data. Vereinigte Informationssysteme Tierhaltung (VIT, Verden) is thanked for providing milk recording data and estimated breeding values.

\section{References}

ADR, 2005. Annual Statistics. German Cattle Breeders Federation. Bonn, Germany.

Amer, P.R., Fox, G.C., Smith, C., 1994. Economic weights from profit equations: appraising their accuracy in the long run. Anim. Prod. 58, 11-18.

Bethge, M., Wensch-Dorendorf, M., Swalve, H.H., 2005. Schätzung von Varianzkomponenten am Material der linearen Exterieurbeschreibung beim Holstein Rind. Vortragstagung der DGfZ und GfT, 21./22.09.05, Berlin.

Blake, R.W., McDaniel, B.T., 1979. Relationship of udder conformation with labor and machine inputs to milk harvest in dairy cattle. J. Dairy Sci. 62, 475-485.

Boettcher, P.J., Dekkers, J.C.M., Kolstad, B.W., 1998. Development of an udder health index for sire selection based on somatic cell score, udder conformation, and milking speed. J. Dairy Sci. 81, 1157-1168.

Bowden, B., 1982. Type classification in dairy cattle: a review. Anim. Breed. Abstr. 50, 147-162.

Brotherstone, S., McManus, C.M., Hill, W.G., 1990. Estimation of genetic parameters for linear and miscellaneous type traits in Holstein-Friesian dairy cattle. Livest. Prod. Sci. 26, 177-192.

Bünger, A., Ducrocq, V., Swalve, H.H., 2001. Analysis of survival in dairy cows with supplement data on type scores and housing systems from a region of northwest Germany. J. Dairy Sci. 84, 1531-1541.

Dechow, C.D., Rogers, G.W., Klei, L., Lawlor, T.J., 2003. Heritabilities and correlations among body condition score, dairy form and selected linear type traits. J. Dairy Sci. 86, 2236-2242.

Devir, S., Renkema, J.A., Huirne, R.B.M., Ipema, A.H., 1993. A new dairy control and management system in the automatic milking farm: Basic concepts and components. J. Dairy Sci. 76, 3607-3616.

Fürst-Waltl, B., Wieser, J., Fürst, C., Sölkner, J., 2004. Einfluss des Exterieurs auf den Versteigerungspreis von Fleckvieh- und Braunvieh-Kalbinnen. Züchtungskunde 76, 149-161.

Gengler, N., Wiggans, G.R., Thornton, L.L.M., Wright, J.R., Druet, T., 2006. Accounting for heterogeneous variances in multitrait evaluation of Jersey type traits. J. Dairy Sci. 89, 3143-3151.

Gilmour, A.R., Cullis, B.R., Welham, S.J., Thompson, R., 2000. ASREML. Program user manual. NSW Agriculture, Orange Agricultural Institute, Forest Road, Orange, NSW, 2800, Australia.

Harris, B.L., Freeman, A.E., Metzger, E., 1992. Genetic and phenotypic parameters for type and production in Guernsey dairy cows. J. Dairy Sci. 75, 1147-1153.

Heringstad, B., Klemetsdal, G., Ruane, J., 2000. Selection for mastitis resistance in dairy cattle-a review with focus on the situation in Nordic countries. Livest. Prod. Sci. 64, 95-106.

König, S., Sharifi, R., Wentrot, H., Landmann, D., Eise, M., Simianer, H., 2005. Genetic parameters of claw and foot disorders estimated with logistic models. J. Dairy Sci. 88, 3316-3325.

König, S., Lessner, S., Simianer, H., 2007. Application of controlling instruments for improvements in cow sire selection. J. Dairy Sci. 90,1967-1980.

Krogmeier, D., Luntz, B., Götz, K.-U., 2006. Untersuchungen zur ökonomischen Bewertung von Exterieurmerkmalen bei Braunvieh und Fleckvieh anhand von Jungkuh-Auktionsdaten. Züchtungskunde 78, 464-478'.

Kuhn, M.T., Boettcher, P.J., Freeman, A.E., 1994. Potential bias in transmitting abilities of females from preferential treatment. J. Dairy Sci. 77, 2428-2437.

Lind, B., Schierenbeck, S., Reinhardt, F., Simianer, H., 2007. Do type traits have an economic value in dairy cows? Proc. 58th EAAP-Meeting, Dublin, Ireland.

Lund, T., Miglior, F., Deckers, J.C.M., Burnside, E.B., 1994. Genetic relationships between clinical mastitis, somatic cell count, and udder conformation in Danish Holsteins. Livest. Prod. Sci. 39, 243-251.

Miglior, F., Muir, B.L., Van Doormaal, B.J., 2005. Selection indices in Holstein cattle of various countries. J. Dairy Sci., 88, 1255-1263.

Mügge, B., Lutz, W.E., Südbeck, H., Zelfel, S., 1999. Deutsche Holsteins: Die Geschichte einer Zucht. Verlag Eugen Ulmer.

Philipsson, J., Ral, G., Berglund, B., 1995. Somatic cell count as a selection criterion for mastitis resistance in dairy cattle. Livest. Prod. Sci. 41, 195-200.

Placke, K.-H. 1982. Untersuchung zur Exterieurbeurteilung in der Schwarzbuntzucht. PhD Thesis, University of Kiel. 
Rogers, G.W., Spencer, S.B., 1991. Relationships among udder and teat morphology and milking characteristics. J. Dairy Sci. 74, 4189-4194.

Ruff, N.J., Vinson, W.E., Pearson, R.E., White, J.M., Meland, O.M., Edlund, D.P., 1983. Factors affecting price differences within sales of registered Holstein cattle. J. Dairy Sci. 66, 587-594.

SAS Institute Inc., 1999. SAS/STAT User's guide, Version 8. Cary, NC, USA.

Schneider, M. del P., Dürr, W.R., Cue, R.I., Monardes, H.G., 2003. Impact of type traits on functional herd life of Quebec Holsteins assessed by survival analysis. J. Dairy Sci. 86, 4083-4089.

Sewalem, A., Kistemaker, G.J., Miglior, F., Van Doormaal, B.J., 2004. Analysis of the relationship between type traits and functional survival in Canadian Holsteins using a Weibull proportional hazards model. J. Dairy Sci. 87, 3938-3946.

Short, T.H., Lawlor, T.J., 1992. Genetic parameters of conformation traits, milk yield, and herd life in Holsteins. J. Dairy Sci. 75, 1987-1998.

Smith, K.L., Hillerton, J.E., Harmon, R.J., 2001. Guidelines on normal and abnormal raw milk based on somatic cell counts and signs of clinical mastitis. NMC, Inc., Madison WI.
Sölkner, J., Willam, A., Gierzinger, E., Egger-Danner, C., 1999. Effects of including conformation in total merit indices of cattle. Interbull. Bull. 23, 143-150.

Swalve, H.H., Flöck, D., 1990. Berücksichtigung von Beurteilermittelwert und standardabweichung als wichtige Einflußgrößen bei der Analyse von Daten der linearen Exterieurbeschreibung. Züchtungskunde 62, 367-383.

Swalve, H.H., Höver, K., 2003. Examinations using the results of breeding value estimation for Holstein sires and cows in Germany. Arch. Tierz. 46,113-126.

Swalve, H.H., König, S., 2007. Testherden in Zuchtprogrammen für Milchrinder. 1. Mitteilung: Allgemeine Überlegungen. Züchtungskunde 79, 249-263.

Trilk, J., Zube, R., May, D., 2005. Management, Kostenaufwand und Wirtschaftlichkeit Automatischer Melksysteme in Auswertung mehrjähriger praktischer Nutzung. Züchtungskunde 77, 256-270.

Veerkamp, R.F., Gerritsen, C.L.M., Koenen, E.P.C., Hamoen, A., De Jong, G., 2002. Evaluation of classifiers that score linear type traits and body condition score using common sires. J. Dairy Sci. 85, 976-983.

Weigel, K.A., Lawlor, T.J., 1994. Adjustment for heterogeneous variance in genetic evaluations for conformation of United States Holsteins. J. Dairy Sci. 77, 1691-1701. 